\title{
MENINGKATKAN KESADARAN AKAN PENTINGNYA BERPENDAPAT DALAM KEHIDUPAN DEMOKRASI INDONESIA MELALUI MEDIA SOSIAL SEBAGAI MAHASISWA
}

\author{
Zahrani Qolbi Khairunnisa, Nardyawan Arifi Ma'ruf, Adrian Wafi Elhaq, \& Khadijah \\ Institut Teknologi Bandung \\ Email: nardyawan1152@gmail.com
}

\begin{abstract}
Abstrak
Kegiatan mengemukakan pendapat di era modern ditunjang dengan adanya media sosial. Keberadaan media sosial membuat penggunanya bisa mengemukakan pendapat tanpa batasan ruang dan waktu. Meskipun begitu, antusiasme masyarakat untuk mengemukakan pendapat cenderung mengalami penurunan. Terlebih lagi antusiasme golongan muda cenderung lebih rendah daripada golongan tua. Jika fenomena sosial ini terus berlanjut, maka kehidupan masyarakat yang demokratis akan tergerus oleh golongan muda yang pasif. Menindaklanjuti permasalahan ini, penelitian diadakan untuk menganalisis penyebab rendahnya kesadaran generasi muda, khususnya mahasiswa, untuk mengemukakan pendapatnya sebagai bentuk keikutsertaan dalam berdemokrasi di Indonesia melalui media sosial. Pengumpulan data dilakukan dengan menggunakan metode survei dan studi pustaka. Hasil analisis mengungkapkan bahwa penyebab rendahnya antusiasme mahasiswa untuk beropini antara lain maraknya berita hoax, cyber bullying dari masyarakat yang kontra, serta hukum yang problematis sehingga dapat memicu kriminalisasi dalam beropini. Hasil analisis ini digunakan untuk merumuskan solusi- solusi yang diharapkan dapat menumbuhkan dan meningkatkan kesadaran akan pentingnya berpendapat sebagai mahasiswa demi terciptanya kehidupan demokratis di Indonesia.
\end{abstract}

Kata Kunci: Kebebasan Berpendapat, Beropini, Media Sosial, Mahasiswa

\begin{abstract}
The activity of expressing opinions in the modern era is supported by the existence of social media. The existence of social media allows users to express opinions without the limitations of space and time. Even so, people's enthusiasm to express opinions tends to decrease. Moreover, the enthusiasm of young people tends to be lower than the old class. If this social phenomenon continues, then the life of a democratic society will be eroded by passive young people. Following up on this problem, the study was conducted to analyze the causes of low awareness of the younger generation, especially students, to express their opinions as a form of participation in democracy in Indonesia through Data collection is done using survey methods and library studies. The results of the analysis revealed that the causes of low enthusiasm of students to have opinions include the rise of hoax news, cyber bullying from the counter society, as well as problematic laws that can trigger criminalization in opinion. The results of this analysis are used to formulate solutions that are expected to foster and raise awareness of the importance of opinion as students for the creation of democratic life in Indonesia.
\end{abstract}

Keywords: Freedom of Opinion, Opinion, Social Media, Students

\section{PENDAHULUAN}

Kemerdekaan setiap warga negara untuk mengemukakan pendapatnya di muka umum menunjukkan tatanan kehidupan masyarakat yang demokratis (Pertiwi \& Hidayah, 2021). UndangUndang No. 9 Tahun 1998 tentang Kemerdekaan Menyampaikan Pendapat di Muka Umum, pada Pasal 1 ayat 1 menjelaskan: "Kemerdekaan menyampaikan pendapat adalah hak setiap warga negara untuk menyampaikan pikiran dengan lisan, tulisan, dan sebagainya secara bebas dan bertanggung jawab sesuai dengan ketentuan peraturan dalam perundang-undangan yang berlaku". Adanya undang-undang ini menunjukkan bahwa Indonesia mengakui eksistensi hak 
kebebasan berpendapat (Setyawati et al., 2021). Sebagai negara yang menganut asas demokrasi, sudah seharusnya Indonesia melindungi keberjalanan hak kebebasan berpendapat, mengingat opini masyarakat sebagai salah satu bentuk peran serta dalam ketatanegaraan sangat dibutuhkan demi terciptanya negara sejahtera yang mengayomi seluruh rakyatnya (Hikmah \& Dewi, 2021).

Jika membahas peran masyarakat dalam memajukan negara, maka salah satu komponen yang krusial adalah mahasiswa sebagai generasi penerus bangsa yang akan berperan besar dalam membentuk masa depan bangsanya (Sofiyatul \& Dewi, 2021). Hal ini tidak terlepas dari kenyataan bahwa seorang mahasiswa menghabiskan hari-harinya untuk mencari menuntut ilmu dalam upaya mencari kebenaran. Dalam prosesnya, muncul kegelisahankegelisahan yang menjadi dorongan untuk melakukan gerakan reformatif. Dalam strata kehidupan masyarakat, mahasiswa termasuk komponen kelas menengah yang di Indonesia, menurut Badan Pusat Statistik, komposisinya mencapai kurang lebih $50 \%$ dari seluruh penduduk Indonesia (Isnaini \& Dewi, 2021). Kondisi ini, membuat Indonesia pada tahun 2030 akan mendapatkan bonus demografi dimana jumlah golongan menengah akan mendominasi kelompok sosial. Hal ini membuat peran mahasiswa dalam membangun masa depan bangsa Indonesia semakin besar (Ulfah et al., 2021). Jumlah mahasiswa yang masif membuat setiap suara menjadi sorotan yang patut untuk dipertimbangkan.

Di masa modern sekarang, kegiatan berdemokrasi dengan mengemukakan pendapat menjadi semakin mudah dengan adanya media sosial. Fitur media sosial sendiri, telah berkembang pesat. Mulai dari mengirim pesan singkat hingga membangun relasi dalam skala besar mungkin dilakukan di media sosial.
Menurut survei Asosiasi Penyelenggara Jasa Internet Indonesia (APJI) kelompok usia produktif merupakan pengguna media sosial terbanyak dengan kelompok usia 1934 tahun sebanyak 49,52\%. Dengan berbagai kelebihan media sosial ini, suara mahasiswa berkesempatan untuk menjangkau masyarakat lebih luas.

Akan tetapi, pada masa kini, kesadaran berpendapat pada masingmasing individu semakin rendah. Terutama di masa pandemi ini, masyarakat kian takut untuk memberikan pendapatnya. Berdasarkan survei dari Indikator Politik Indonesia mengenai 'Politik, Demokrasi, dan Pilkada di Era Pandemi,' didapatkan data sebanyak $21,9 \%$ dari responden sangat setuju mengenai semakin takutnya masyarakat untuk berpendapat. Sebanyak 47,7\% responden agak setuju dengan hal itu, kemudian $22 \%$ kurang setuju, dan sisanya yaitu $3.6 \%$ tidak setuju sama sekali. Turunnya minat berpendapat mungkin disebabkan oleh beberapa kasus pembatasan kebebasan berpendapat contohnya seperti yang terjadi pada beberapa mahasiswa Universitas Sebelas Maret (UNS) karena aksi pembentangan poster berisi kritik kepada Presiden Jokowi. Kasus-kasus ini justru dapat menurunkan keberanian pada mahasiswa untuk mengungkapkan pendapatnya.

Berdasarkan kondisi yang telah dipaparkan, penelitian diadakan untuk menelaah lebih dalam perihal kondisi demokrasi masyarakat Indonesia terutama mahasiswa dalam beropini di media sosial sebagai bentuk kontribusi dalam pengawasan dunia politik maupaun perkembangan negara Indonesia. Diharapkan hasil penelitian ini dapat membantu mengetahui faktor-faktor penyebab kalangan mahasiswa kurang antusias untuk beropini dalam publik serta mampu memformulasikan solusi yang efektif untuk meningkatkan kesadaran 
mahasiswa akan pentingnya suara mereka dalam demokrasi Indonesia.

\section{METODE PENELITIAN}

Pengumpulan data dalam penelitian ini melibatkan metode studi pustaka dan survei. Studi pustaka dilakukan dengan mencari sumber literatur online di berbagai situs penyedia jurnal, buku, dan literatur lain yang relevan dengan topik yang penulis angkat. Setelah literatur terkumpul, informasi yang didapat digunakan untuk menyusun teori-teori yang tercantum dalam hasil penelitian ini. Selain itu, informasi yang didapat juga digunakan untuk membantu dalam penyusunan hasil pembahasan dan analisis data yang diperoleh sehingga diharapkan hasil penelitian ini dapat menjadi sumber informasi yang kredibel. Teknik ini digunakan karena relatif cepat dan tidak banyak memakan biaya. Survei dilakukan untuk mendapatkan data lapangan yang relevan terhadap topik yang diangkat penulis. Target survei ini adalah mahasiswa Indonesia dengan latar belakang daerah berbeda-beda. Dengan memanfaatkan media formulir online yang berisi pertanyaan kuantitatif dan kualitatif, pendapat responden dikumpulkan untuk diolah dan divisualisasikan dalam bentuk grafik kemudian dianalisis. Teknik ini digunakan dengan harapan pembahasan yang dilakukan relevan terhadap kenyataan di lapangan.

\section{HASIL PENELITIAN DAN PEMBAHASAN Hasil Penelitian}

Melalui survei yang telah dilakukan, terkumpul data dari 105 responden yang merupakan mahasiswa dari berbagai wilayah di Indonesia. Dari survei tersebut diperoleh data pandangan responden akan kondisi demokrasi di Indonesia khususnya perihal kebebasan berpendapat. Hasil analisis data menunjukkan sebanyak 38 responden $(36,2 \%)$ berpandangan bahwa
Indonesia sekarang ini kurang demokratis. Sebanyak 31 responden (29,5\%) beranggapan cukup demokratis dan 26 responden $(24,8 \%)$ beranggapan biasa saja.

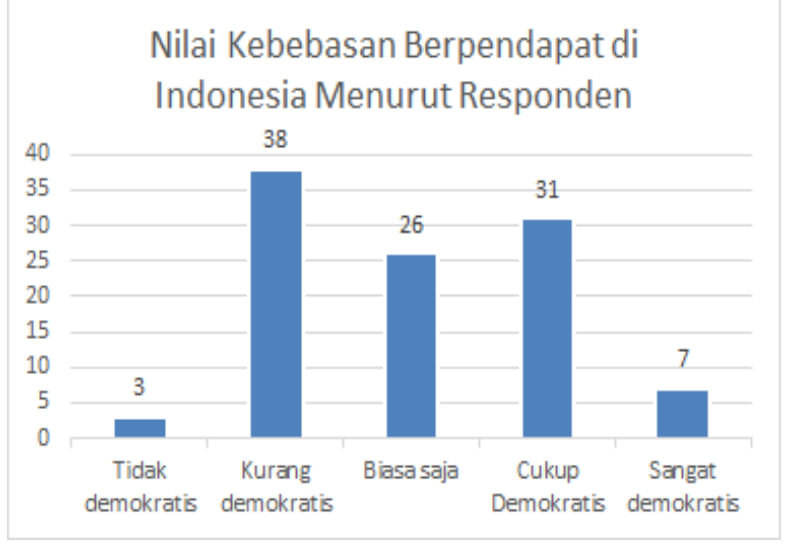

Gambar 1. Pandangan responden akan kondisi demokrasi di Indonesia

Dari data survei tentang pandangan responden akan kondisi demokrasi di Indonesia, terlihat cukup banyak mahasiswa yang beranggapan bahwa kondisi Indonesia yang sekarang kurang demokratis. Anggapan ini bisa muncul akibat insiden-insiden pembungkaman pendapat dalam kegiatan pergerakan mahasiswa. Tidak bisa dipungkiri bahwa peristiwa-peristiwa tersebut telah menaruh pengaruh negatif terhadap mahasiswa lainnya sehingga mereka berpandangan bahwa Indonesia menjadi kurang demokratis. Kondisi ini menimbulkan intimidasi terhadap mahasiswa untuk berperan aktif dalam kegiatan berdemokrasi.

Berdasarkan hasil survei, sebanyak 50 responden $(47,6 \%)$ menggunakan media sosial selama 2-5 jam per hari, 30 responden $(28,6 \%)$ selama 5-8 jam per hari, dan bahkan 16 responden $(15,2 \%)$ menggunakan media sosial lebih dari 8 jam per harinya. 


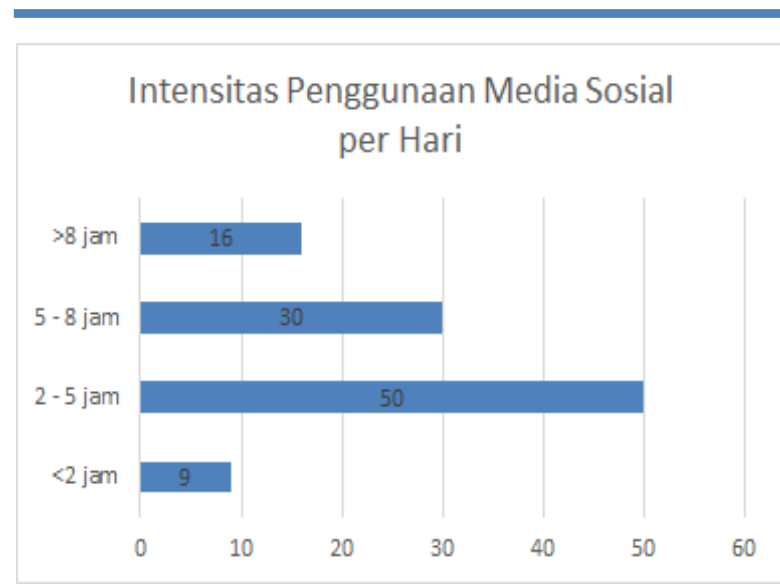

Gambar 2. Intensitas responden dalam menggunakan media sosial per hari

Pada data selanjutnya juga terlihat mayoritas responden berpendapat bahwa media sosial adalah sarana yang menawarkan kebebasan berekspresi bagi setiap orang. Kedua data ini memberi kesimpulan bahwa media sosial adalah sarana yang potensial dalam berekspresi, mengemukakan pendapat, dan bertukar pikiran.

Efektivitas Penggunaan Media Sosial sebagai Sarana untuk Bebas Berekspresi

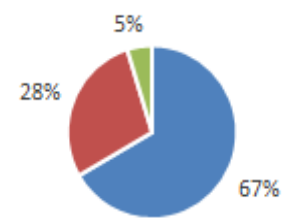

- Ya, setiap orang bebas ber ekpr esi di media sosial

- Kurang

- Tidak, media sosial tidak menawarkan kebebasan ber ekspresi

Gambar 3. Pandangan responden akan media sosial sebagai media beropini
Antusiasme Mahasiswa Beropini Terkait Isu

Politik di Media Sosial

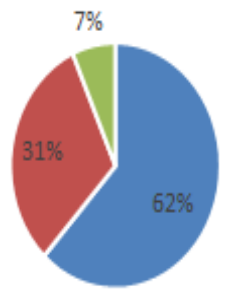

- Tidak - Lumayan "Ya

\section{Gambar 4. Antusiasme mahasiswa dalam beropini terkait isu politik}

Akan tetapi, hasil di atas berbanding terbalik dengan tingkat antusiasme mahasiswa dalam beropini khususnya terkait isu politik. Hal ini menunjukkan media sosial sebagai sarana berekspresi tidak berdampak efektif terhadap keikutsertaan mahasiswa dalam isu politik. Media sosial lebih banyak digunakan sebagai media bersenang-senang bagi mahasiswa.

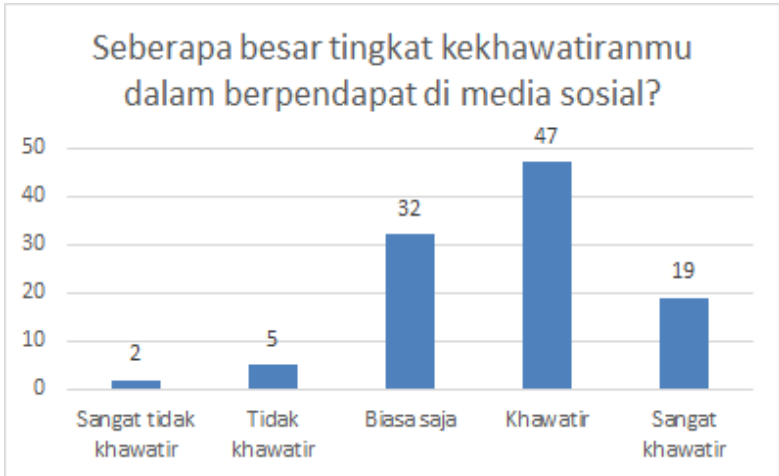

Gambar 5. Tingkat kekhawatiran responden dalam beropini di media sosial

Berdasarkan data diatas, 47 responden $(44,7 \%)$ merasa khawatir untuk berpendapat di media sosial dan 19 responden (18.1\%) merasa sangat khawatir. Kekhawatiran yang tinggi menunjukkan sebenarnya para mahasiswa memiliki perhatian terhadap isu politik dan berkeinginan untuk menyampaikan 
keresahan dan pendapatnya di media sosial. Logikanya jika mereka tidak memiliki perhatian, tentu tidak akan muncul keresahan, lalu tidak akan ada keinginan untuk beropini, sehingga seharusnya tidak ada sumber kekhawatiran. Faktanya keinginan itu ada, tetapi tertahan untuk menyampaikannya karena alasan tertentu.

Menurut hasil survei, kekhawatiran yang tinggi ini berhubungan dengan adanya pengaturan dan penerapan undang-undang yang problematis dan kurang terspesifikasi terkait beropini di media sosial. Undang- undang ini kerap dijadikan senjata untuk memperkarakan seseorang yang menyampaikan kritiknya di media sosial. Alasan selanjutnya adalah potensi dan banyaknya kasus cyber bullying dari masyarakat yang berseberangan pendapat. Semua masyarakat Indonesia pengguna aktif media sosial pasti sadar bahwa masih banyak masyarakat yang kurang bertoleransi dengan perbedaan pendapat dan cenderung anarkis dalam menanggapinya. Bullying ini bahkan bisa berlanjut ke teror dan kejahatan di kehidupan nyata si pengirim. Lebih parahnya lagi, masyarakat Indonesia masih banyak yang lebih percaya dengan hoax dan minim literasi. Ini menyebabkan perbedaan pendapat sangat sering terjadi dan susah diselesaikan. Alasan lainnya adalah adanya block atau take down terhadap akun atau unggahan yang dilakukan oleh komunitas pada media sosial yang digunakan.

Secara keseluruhan, media sosial merupakan salah satu alat yang dapat digunakan mahasiswa untuk mengemukakan pendapatnya (Nurgiansah, 2018). Media sosial telah menjadi ruang bagi banyak mahasiswa untuk bertukar informasi dan berekspresi secara leluasa. Akan tetapi, beberapa oknum tak jarang menyalahgunakan kebebasan dalam menggunakan media sosial sehingga sering kali menimbulkan perselisihan dan intimidasi. Hal ini menjadi salah satu penyebab menurunnya antusiasme mahasiswa untuk beropini terkait suatu isu dalam media sosial. Sebagian besar mahasiswa memilih posisi yang aman dengan hanya memanfaatkan media sosial sebagai sarana hiburan namun pasif menanggapi isu-isu yang terjadi di Indonesia.

Menanggapi kondisi rendahnya antusiasme mahasiswa dalam beropini, beberapa hal yang dapat dilakukan untuk meningkatkan antusiasme mahasiswa agar aktif menyuarakan pendapatnya adalah dengan meninjau ulang penegakan UU ITE, dimana fokus tujuannya adalah untuk melindungi hak-hak kebebasan berpendapat warga negara sehingga peristiwa cyberbullying dapat diminimalisir (Nurgiansah, 2021). Peninjauan ulang perihal undang-undang yang mengatur tentang hak kebebasan berpendapat secara umum perlu dilakukan sehingga demi tercapainya hukum yang efektif dan objektif menghindari terjadinya multitafsir yang dapat membuka celah untuk disalahgunakan.

Hal lain yang dapat dilakukan adalah menegakkan hak kebebasan berpendapat di media sosial sehingga tercipta ruang kondusif dan efektif dalam penyampaian pendapat. Hal ini dapat diwujudkan dengan memberikan edukasi terhadap masyarakat akan etika penggunaan media sosial yang dapat disampaikan melalui sosialisasi, broadcast, maupun sebagai bahan pembelajaran di lingkungan pendidikan. Selain itu, peran aktif pemerintah dalam memberikan tanggapan-tanggapan positif terkait pendapat atau kritik dari mahasiswa maupun masyarakat lainnya melalui media sosial sangatlah dibutuhkan demi menghidupkan suasana positif yang mencerminkan betapa pentingnya hak 
kebebasan berpendapat di media sosial. Dengan adanya tanggapan positif tersebut, mahasiswa dan masyarakat yang telah berusaha untuk aktif ikut serta berdemokrasi dalam bentuk penyampaian pendapat merasa lebih dihargai karena aspirasinya berarti dan telah tersampaikan dengan baik.

\section{KESIMPULAN}

Berdasarkan hasil survei yang didapat, media sosial merupakan media yang cukup efektif untuk menyuarakan pendapat. Namun, mayoritas mahasiswa menggunakan media sosial hanya sebagai media hiburan dan sarana berkomunikasi sehingga antusias mahasiswa dalam berpendapat terkait isu-isu politik rendah. Hal ini disebabkan oleh faktor-faktor pembatas seperti cyber bullying, hoax, block dan takedown yang mudah dilakukan pihak kontra, kriminalitas serta ancaman dan beberapa peraturan pemerintah yang problematis terkait media sosial. Untuk meningkatkan antusias mahasiswa dalam beropini di media sosial, dapat dilakukan dengan cara mengurangi faktor faktor pembatas yang ada seperti salah satunya mempertegas kembali UU ITE. Melakukan seleksi dan konfirmasi atas peredaran berita di dunia maya untuk meminimalisir berita hoax. Mengedukasi masyarakat akan pentingnya etika penggunaan media sosial. Pembuatan poster dan artikel menarik tentang pemahaman berpendapat di media sosial juga dapat dilakukan.

Berlandaskan analisis hasil penelitian dan studi pustaka terdapat beberapa masukan dari kami yang dirasa dapat berguna untuk menanggulangi fenomena rendahnya minat beropini pada mahasiswa di media sosial. Berikut beberapa masukan yang diajukan. Pertama, pemerintah hendaknya lebih mempertegas dan memperjelas hukum mengenai aturan dalam beropini di masyarakat sekitar, terutama beropini pada media sosial. Hukum yang berlaku tidak boleh disalahgunakan seperti untuk menakut- nakuti ataupun membungkam pihak tertentu supaya tidak dapat bersuara dan beropini dengan bebas. Kedua, Edukasi terkait etika dalam beropini terutama di media sosial kepada masyarakat sekitar. Masyarakat sudah semestinya paham tentang keberadaan dan bahayanya penyebaran berita palsu atau hoax serta berita yang diselewengkan kebenarannya. Tidak hanya itu, masyarakat juga harus dapat mengatur emosi ketika beropini di media sosial. Maka dari itu, pengalaman kurang baik dalam beropini di media sosial dapat diminimalisir sebaik mungkin. Ketiga, Mahasiswa selaku generasi penerus bangsa, harus menyadari jika pemikiran, opini, dan suara mereka begitu berarti untuk keberlangsungan bangsa serta negeri ke depannya. Oleh sebab itu, hendaknya mahasiswa lebih berempati terhadap keadaan lingkungan di sekitarnya. Hanya dengan beropini saja, kita dapat menunjukkan bahwa kita masih peduli dan sanggup untuk membenahi permasalahan yang tengah berlangsung saat ini.

\section{DAFTAR PUSTAKA}

Abiyyu, Farid (2021, April 22). Kebebasan Berpendapat dan Berekspresi Generasi Muda di Media Sosial dalam Perspektif Libertarianisme.

Budiman, Arif. 1984. "Peranan Mahasiswa sebagai Intelegensia dalam Cendekiawan dan Politik". Jakarta, LP3ES.

Hamersley, Martyn dan Atkinson, Paul. 2007. Ethnography: Principles in Practice. London and New York: Routledge

Hikmah, S. N., \& Dewi, D. A. (2021). Meninjau Sejauh Mana Implementasi Nilai Pendidikan 
Karakter Melalui Pendidikan Kewarganegaraan di Perguruan Tinggi. Jurnal Kewarganegaraan, $5(2)$ 417-425. https://journal.upy.ac.id/index.php/pkn/article/view/1745

Isnaini, P. N., \& Dewi, D. A. (2021). Upaya Menerapkan Nilai-Nilai Pancasila Di Masa Pandemi $\begin{array}{llr}\text { Covid-. Jurnal Kewarganegaraan, } & \text { 5(2), }\end{array}$ https://journal.upy.ac.id/index.php/pkn/article/view/1344

Nurgiansah, T. H. (2018). Pengembangan Kesadaran Hukum Berlalu Lintas Siswa Melalui Model Pembelajaran Jurisprudensial Dalam Pendidikan Kewarganegaraan (Studi Kasus di SMK Bina Essa Kabupaten Bandung Barat Kelas X Administrasi Perkantoran). Tesis. Repository Universitas Pendidikan Indonesia, Oktober. http://ieeeauthorcenter.ieee.org/wp-content/uploads/IEEE-Reference-

Guide.pdf\%0Ahttp://wwwlib.murdoch.edu.au/find/citation/ieee.html\%0Ahttps://doi.or g/10.1016/j.cie.2019.07.022\%0Ahttps://github.com/ethereum/wiki/wiki/WhitePaper\%0Ahttps://tore.tuhh.de/hand

Nurgiansah, T. H. (2021). Pendidikan Pancasila Sebagai Upaya Membentuk Karakter Jujur. Jurnal Pendidikan Kewarganegaraan Undiksha, 9(1), 33-41.

Pertiwi, S. G., \& Hidayah, Y. (2021). Implementasi Pendidikan Hak Asasi Manusia dalam Dunia Pendidikan Sekolah Dasar. Jurnal Kewarganegaraan, 5(2), 376-380. https://journal.upy.ac.id/index.php/pkn/article/view/1717

Setyawati, Y., Septiani, Q., Aulia Ningrum, R., \& Hidayah, R. (2021). Imbas Negatif Globalisasi terhadap Pendidikan di Indonesia. Jurnal Kewarganegaraan, 5(2), 306-315. https://docplayer.info/214608960-Imbas-negatif-globalisasi-terhadap-pendidikan-diindonesia.html

Sofiyatul, N., \& Dewi, A. (2021). SKKP BAWASLU Sebagai Sarana Pendidikan Politik dalam Upaya meningkatkan Partisipasi Politik Warga Negara. Jurnal Kewarganegaraan, 5(2), 355-363.

Ulfah, N., Hidayah, Y., \& Trihastuti, M. (2021). Urgensi Etika Demokrasi di Era Global: Membangun Etika dalam Mengemukakan Pendapat bagi Masyarakat Akademis Melalui Pendidikan Kewarganegaraan. Jurnal Kewarganegaraan, 5(2), 329-346. https://journal.upy.ac.id/index.php/pkn/article/view/1576 